\title{
Sangue e fígado: a persistência das imagens simbólicas sobre a lepra a partir do mito do Papa-Figo
}

\author{
Blood and liver: the persistence of the leprosy symbolic images considering \\ the Papa-Figo myth
}

\section{Sangre e hígado: la persistencia de las imágenes simbólicas de la lepra a partir del mito de Papa-Figo}

\author{
Andriolli Costa ${ }^{1, a}$ \\ andriolli_costa@hotmail.com | http://orcid.org/oooo-00o2-8589-2751 \\ ${ }^{1}$ Universidade Federal do Rio Grande do Sul. Porto Alegre, RS, Brasil. \\ a Doutorado em Comunicação e Informação pela Universidade Federal do Rio Grande do Sul.
}

\section{Resumo}

Este artigo volta-se para os processos simbólicos que, frente à iminência do adoecimento e da morte, fazem emergir no imaginário poderosas narrativas que se dinamizam em mitos. Elege, para isso, as imagens simbólicas sobre a lepra que circundam o mito do Papa-Figo - criatura fantástica, ele é representado por ricos e poderosos que, contaminados, fariam de tudo para recuperar sua saúde; inclusive consumir vísceras de crianças sequestradas. Em um percurso sincrônico e diacrônico, relacionamos relatos históricos e folclóricos com narrativas contemporâneas: vídeos de exploração à casa da 'viúva Papa-Figo'. Nesta leitura simbólica, exploramos a recorrência dos símbolos de sangue, fígado, poço, poder, dinheiro e de um Outro misterioso, mostrando que o medo da doença e suas consequências físicas e sociais nos movimentam arquetipicamente, despertando relações ancestrais que nos conectam com o plano da experiência humana.

Palavras-chave: Imaginário; Mito; Lepra; Folclore; Símbolo.

\begin{abstract}
This article is focused on the symbolic processes that, in the face of the imminence of illness and death, make powerful narratives emerge in the imaginary, which are symbolized by myths. For this purpose, we center on the symbolic images on leprosy that surround the Brazilian myth of the Papa-Figo - a fantastic creature represented by the rich and powerful people which were contaminated and would do anything to recover from the illness and back to their health; including consuming the entrails of kidnapped children.
\end{abstract}


In a synchronic and diachronic journey, we related historical and folkloric reports to contemporary narratives: urban exploration videos exploring the abandoned house of the 'Papa-Figo widow'. In this symbolic reading, we explore the recurrence of symbols linked to blood, liver, well, power, money and the mysterious Other, showing that the fear of disease and its physical and social consequences move us archetypically, awakening ancestral relationships that connect us to the experience human level

Keywords: Imaginary; Myth; Leprosy; Folklore; Symbol.

\section{Resumen}

Este artículo se centra en los procesos simbólicos que, en vista de la inminencia de la enfermedad y de la muerte, hacen que surjan narrativas poderosas en el imaginario simbolizadas en mitos. Para este propósito, elegimos las imágenes simbólicas sobre la lepra que rodean el mito brasileño llamado Papa-Figo, una criatura fantástica representada por personas ricas y poderosas que, contaminadas con la enfermedad, harían cualquier cosa para recuperar su salud; incluyendo el consumo de las entrañas de niños secuestrados. En un camino sincrónico y diacrónico, relacionamos los relatos históricos y folclóricos con narrativas contemporáneas: vídeos de exploración urbana a la casa de la 'viuda Papa-Figo'. En esta lectura simbólica exploramos la recurrencia de símbolos vinculados a la sangre, al hígado, al pozo, al poder, al dinero y al Otro misterioso, mostrando que el miedo a la enfermedad y sus consecuencias físicas y sociales nos mueven arquetípicamente, despertando relaciones ancestrales por las cuales nos conectamos con el plano de la experiencia humana.

Palabras clave: Imaginário; Mito; Lepra; Folklore; Símbolo.

Contribuição dos autores:

Concepção e desenho do estudo: Andriolli Costa.

Aquisição, análise ou interpretação dos dados: Andriolli Costa.

Redação do manuscrito: Andriolli Costa.

Revisão crítica do conteúdo intelectual: Andriolli Costa.

Declaração de conflito de interesses: não há.

Fontes de financiamento: Coordenação de Aperfeiçoamento de Pessoal de Nível Superior.

Agradecimentos/Contribuições adicionais: não há.

Histórico do artigo: submetido: 14 ago. 2019 | aceito: 19 abr. 2020 | publicado: 30 jun. 2020.

Apresentação anterior: não houve.

Licença CC BY-NC atribuição não comercial. Com essa licença é permitido acessar, baixar (download), copiar, imprimir, compartilhar, reutilizar e distribuir os artigos, desde que para uso não comercial e com a citação da fonte, conferindo os devidos créditos de autoria e menção à Reciis. Nesses casos, nenhuma permissão é necessária por parte dos autores ou dos editores. 


\section{Introdução}

Diante da angústia que acompanha o disseminar de uma nova pandemia, muito do comportamento humano se revela. Na culminância da era da comunicação, quando os avanços do Coronavirus Disease 2019 (Covid-19) pelo globo podem ser acompanhados praticamente em tempo real, e na qual dispomos de uma democratização da informação em níveis nunca antes experimentados, ainda assim somos tensionados por processos que nos desafiam a tal ponto, que as respostas fornecidas pela razão científica e pela objetividade moderna se mostram insuficientes. O medo, a insegurança e a incerteza movimentam pavores ancestrais que vão além da factualidade do acontecimento imediato e se conectam conosco no plano de uma experiência humana fundamental. No plano do imaginário.

Percebemos processos semelhantes no decorrer da história. Ao longo dos séculos, a doença e a peste foram frequentemente entendidas como castigos ou punições sagradas. E se no passado esta culpa já foi compreendida em âmbito coletivo - como ofensas de uma cidade inteira ou os pecados familiares da mitologia grega que passavam de geração para geração ${ }^{1}$ - com o cristianismo, a referida culpa se torna cada vez mais individualizada. Incidia sobre o próprio doente a responsabilidade pela 'cruz' que carregava. Se algo de ruim acontecia, não era sem motivo. Deste modo, não apenas o enfermo passava a buscar na sua biografia a anamnese para seu sofrimento, mas também as pessoas do entorno se mostravam incapazes de evitar o julgamento. A doença, problematiza Susan Sontag, passa a servir então como metáfora; uma figura de linguagem para sintetizar ações, comportamentos e sentimentos questionados pelo grupo social que a vivencia ${ }^{2}$

Em suas reflexões, a autora se debruça sobre obras literárias de renome para depreender as fabulações que mobilizam uma "mitologia" sobre as doenças; em especial a tuberculose, o câncer e, mais tarde, a aids². A escolha do termo em destaque dialoga com as reflexões de Roland Barthes, para quem o mito não passava de um "saber confuso constituído por associações frágeis, limitadas”3. Frente a estes 'estereótipos' naturalizados, caberia ao pesquisador empreender um processo de desvelamento, a desmitificação, para que o verdadeiro conhecimento fosse então produzido.

Todavia, existem outras perspectivas acadêmicas sobre o termo. Para a teoria geral do imaginário de vertente arquetipológica, com a qual este trabalho se alinha, 'mito' é o imaginário dinamizado em narrativa4. Uma ideia-forma tão potente que é capaz de orientar modos de sentir, pensar e agir de um povo. Assim, com vistas a essas pulsões ancestrais que inspiram a ações concretas no presente, a discussão de se a narrativa em si é ou não correspondente a uma factualidade - alçando, assim, o estatuto de 'verdadeira' - perde relevância.

Exposição feita, este artigo opta por investigar a relação do humano com a doença a partir desse segundo ponto de mirada. Sua a atenção se volta para os processos simbólicos que fazem emergir no imaginário um arcabouço de narrativas decorrentes da angústia frente à iminência do adoecimento e da morte. Nosso objetivo, portanto, é refletir sobre os modos como essas histórias que se espalharam boca a boca sobrevivem na tradição e persistem em ecos midiáticos, à revelia de qualquer registro ou explicação oficial.

O objeto sobre o qual nos debruçaremos serão as imagens simbólicas que constelam em torno da relação entre a hanseníase - a 'lepra' milenar, que alçou níveis epidêmicos no Brasil do início do século XX - e o mito do Papa-Figo, uma criatura fantástica bastante conhecida na cultura popular do nordeste do país. A narrativa fala de homens e mulheres ricos e poderosos que, contaminados por uma doença que traz as mesmas características da causada pelo bacilo de Hansen, fazem de tudo para recuperar sua saúde. De banhar-se com sangue de crianças a sequestrá-las para comer seu fígado.

Para isto, seguiremos como metodologia a "leitura simbólica" orientada por Gilbert Durand ${ }^{4}$, fundador da teoria do imaginário, que sugere enquanto 'mitodologia' a busca pela redundância de imagens que se repetem em textos culturais, de modo a compor um panorama sincrônico e diacrônico na análise da 
pregnância dos símbolos. As idas e vindas do texto serão guiadas pelas imagens mais evidentes que se interrelacionam nessa doença: Sangue e Fígado. O primeiro, cuja corrupção geraria a lepra; e o segundo, por sua vez, visto como indicativo de processo ancestral de cura - uma vez que na vulgata é visto como produtor e renovador do sangue. A essas leituras, relacionaremos o histórico da doença no país e os contextos sociais que colaboraram para gerar o medo e, como diria Bachelard 5 , (de)formar imagens.

A título de exposição, de modo a sustentar a leitura simbólica, observaremos a persistência dessas imagens - colhidas inicialmente nos relatos de pesquisadores da cultura popular - frente a novas narrativas desenvolvidas em um formato extremamente contemporâneo de conteúdo: canais do YouTube de exploração urbana. No caso, jovens inspirados por uma tendência estrangeira de incursões a 'casas malassombradas' e que buscam mimetizar esta experiência dentro de suas próprias territorialidades. Nesta análise, percebemos que em contato direto com o espaço dos acontecimentos, a fabulação toma conta e o que sobrevive é justamente o que permanece gravado no imaginário popular.

Cabe ressaltar que os referidos relatos do início do século XX que dão conta do avançar da lepra no Brasil e da consolidação das narrativas sobre a doença na oralidade foram selecionados a partir de um resgate bibliográfico, tendo como eixo referências ao mito do Papa-Figo em obras de registro folclórico como em Câmara Cascudo e Gilberto Freyre, que derivaram na consulta a teses, dissertações, livros de memorialistas e tratados do Serviço Nacional de Lepra, sendo todos tratados igualmente enquanto textos culturais impregnados do imaginário do seu tempo. Desta forma, ainda que de outro ponto de mirada, concordamos com o historiador Vitor Hugo Néia que identifica nos registros folclóricos "fontes extremamente valiosas para a escrita da História”' uma vez que estes são constituídos de práticas humanas que se transformam continuamente no tempo e no espaço.

Contudo, nosso ponto de mirada não é nem o da História, nem o do Folclore em si, mas sim o do Imaginário: cimento social que nos permite partilhar um arcabouço de sentidos. A obra cultural está prenhe de imagens, independentemente de ser texto literário, livro teórico ou vídeo para o YouTube. Afinal, o imaginário tudo perpassa, e encontra no registro humano seu locus fecundo.

Como elucida Michel Maffesoli, "o imaginário é uma força social de ordem espiritual, uma construção mental, que se mantém ambígua, perceptível, mas não quantificável. [...] Algo que envolve e ultrapassa a obra. Esta é a ideia fundamental de Durand: nada se pode compreender da cultura caso não se aceite que existe uma espécie de 'algo mais', uma ultrapassagem, uma superação da cultura. Esse algo mais é o que se tenta captar por meio da noção de imaginário"”.

Tal abordagem, que mergulha no substrato da imagética humana compartilhada, se justifica diante do exposto por Andrea Kitta ${ }^{8}$ na sua investigação sobre os mitos de doenças e contágios nos Estados Unidos: a recorrência dos temas.

Sempre que surge um novo vírus ou epidemia nova, o medo do outro desconhecido e do diferente derivam em reações de misoginia, homofobia, racismo ou medo do imigrante. $\mathrm{O}$ embate entre o institucional e o tradicional se revertem em incomunicabilidade e abuso de autoridade (veremos exemplos claros disso no mito brasileiro do Papa-Figo que selecionamos para o trabalho). Conhecer e compreender estas tendências antropológicas podem ajudar a lançar luz sobre o que pode estar sendo negligenciado no trato e na comunicação sobre doenças.

\section{Casas de Lázaro}

Conhecida desde o antigo Egito, a doença hoje chamada hanseníasei está presente há séculos na literatura ocidental - mesmo que nem sempre de maneira explícita. Uma das menções mais lembradas, por certo,

\footnotetext{
i Reconhecendo todo o lastro negativo que o termo lepra e leproso possuem, utilizaremos os termos ao longo do texto justamente por ser daí que se depreende o imaginário sobre a doença.
} 
é a da parábola do Rico e o Lázaro, na Bíblia cristã. A referência é tão marcante que o nome do mendigo da narrativa, que sofreu em vida para depois ascender aos céus, ganhou lugar de metonímia. É por isso que os hansenianos passaram a ser igualmente apontados como lázaros ou 'lazarentos', na forma adjetiva. Entretanto, a doença em momento algum é mencionada nos versículos correspondentes. Tudo o que se fala é que o mendicante possuía o corpo coberto de chagas ou úlceras, que eram lambidas pelos cachorros de rua9 .

Se em certas obras a identificação com a doença foi feita a posteriori, em outras encontramos o oposto; sua atribuição a males alheios. Ainda no século XVI, José de Anchieta registrava os horrores de uma doença que acometia os indígenas: "Cobre-se todo o corpo dos pés à cabeça de uma lepra mortal, que parece couro de cação e ocupa logo a garganta por dentro e a língua, de maneira que com muita dificuldade se podem confessar e, em três ou quatro dias, morrem"”. . O relato prossegue, informando que os que sobrevivem tem a carne de tal maneira apodrecida que os vermes faltavam lhes comer vivos.

Uma vez que a doença transmitida pelo bacilo de Hansen não mata com tamanha velocidade, caso possamos confiar no relato do cronista, certamente devia se tratar de outra moléstia. Fica, portanto, o nome atrelado a enfermidades semelhantes, que violam e deformam o corpo de alguma maneira. É o que explica outra confusão frequente entre lepra e elefantíase, por exemplo, o que dificultaria as constatações na literatura. Entre os indígenas no Brasil também não havia uma palavra específica para a doença. Em Guarani, registra Maurano, lepra é chamada simplesmente de 'doença feia' (Mbá asy vai), categoria na qual ela não se mostra exclusiva ${ }^{11}$.

Para que se possa identificar menções a doença, portanto, não basta observar o nome, mas sim os sintomas. Entre os principais, podemos citar o comprometimento dos nervos periféricos - causando a perda de sensibilidade que pode levar a feridas ou perda de dedos. Caroços e inchaços podem afetar orelhas, mãos e cotovelos. A musculatura também atrofia, gerando a deformidade que a própria medicina identifica como 'mãos em garra'ii; oferecendo a imagem perfeita para que o imaginário popular construa seus monstros. Há de se lembrar ainda do surgimento de manchas de pele por todo o corpo, com alteração de temperatura no local afetado por elas. É mais um índice amplamente investigado pela medicina ancestral, uma vez que desde Hipócrates (420 a.C), o desequilíbrio dos humores - e com eles, da temperatura corporal - era a explicação para as doenças e o ponto de partida para sua terapêutica.

Tida como o grande desafio sanitarista do início do século XX, a introdução da lepra no Brasil foi durante muito tempo atribuída aos negros africanos. Devido às terríveis condições sub-humanas que lhes eram impostas, relatos de escravizados que contraíram a doença nos navios negreiros realmente eram comuns ${ }^{12}$. Todavia, como explica o 'Tratado de Leprologia' publicado pelo Serviço Nacional de Lepra, é provável que isto não seja verdadeiro. Afinal, os compradores de escravos possuíam uma espécie de manual indicando explicitamente quais escravos não deveriam ser aceitos na lavoura ou no engenho - e a lepra era elemento de exclusão; "Examinavam-nos, nos pontos que eram expostos à venda, parte por parte, e rigorosamente a pele, para verificar se eles estavam ou não atacados de males incuráveis"11.

Com o avanço da colonização e o fortalecimento dos processos de agregação urbana, aliados às baixas condições de higiene, o país encontrou as condições ideais para o surgimento de inúmeros focos da doença, trazida dos países europeus. E não demorou para que sua disseminação ganhasse ares da calamidade pública.

Durante muito tempo foram entidades privadas, principalmente ligadas à Igreja, as responsáveis pelo atendimento aos doentes. Já em 1714, no Recife, é fundado o primeiro Asilo de Lázaros do país, mais tarde transformado no Hospital de Lázaros que permaneceu em atuação até 1941. O local foi desativado após a inauguração da Colônia de Mirueira, o leprosário federal de Pernambuco, reflexo de uma política de exclusão que varreu o Brasil a partir dos anos 1920. Mais do que apenas uma casa de tratamento, era um

ii Ministério da Saúde (BR). Hanseníase: o que é, causas, sinais e sintomas, tratamento, diagnóstico e prevenção. [Internet]; S/D [citado em 2020 mar. 29]. Disponível em https://saude.gov.br/saude-de-a-z/hanseniase 
espaço de reclusão onde os leprosos eram afastados de todo o convívio social, uma vez que a profilaxia até então conhecida era o isolamento dos doentes ${ }^{11}$.

A prática teve eco no movimento sanitarista que marcou a Primeira República enquanto tentativa de dar, ao país, os ares da modernidade. Um dos nomes mais conhecidos do período certamente foi o de Oswaldo Cruz que, em 1904, já havia causado controvérsia com sua campanha de vacinação à força contra a febre amarela, que teve como reação a conhecida Revolta da Vacina. Cruz sempre foi grande incentivador do isolamento dos leprosos, medida que mesmo na época gerou alguma contestação ${ }^{11}$.

Outro grande agente que atuou em prol da reclusão compulsória dos hansenianos foi o sanitarista Emílio Ribas, que justificava o "isolamento humanitário"11 como uma necessidade já comprovada por países europeus. O médico defendia que os asilos-colônia deveriam fornecer aos enfermos condições de distração, conforto e trabalho semelhante às dos sãos. Escreve, citado por Maurano: "A sociedade, que tira desses doentes a liberdade, tem o dever imperioso de assegurar-lhes o bem estar material e tudo o que possa atenuar a crueldade de sua sorte"11.

Na prática, por outro lado, havia muito pouco de humanitário no confinamento, que virou lei federal em 1949. A ação submetia o interno a todo tipo de violência, inclusive sob a norma da proteção das famílias. A legislação permitia, por exemplo, separar os filhos dos pacientes que engravidassem dentro das colônias. Ainda bebês, as crianças eram enviadas em cestos a educandários e preventórios, espécie de creches de filhos considerados órfãos, mesmo tendo pais vivos. Segundo a Secretaria de Direitos Humanos, foram 40 mil bebês separados dos pacientes ${ }^{14}$ até 1986 , período em que a legislação de isolamento compulsório vigorou. Entidades como o Movimento de Reintegração das Pessoas Atingidas pela Hanseníase trabalham até hoje para a construção de pontes com este pedaço da história.

\section{Sangue e fígado}

Vamos nos atentar para as consequências dessa política de controle da vida estabelecida pelo Estado. Os asilos colônia eram praticamente campos de concentração onde os doentes - especialmente os pobres eram obrigados a se recolher. Os ricos, dependendo do caso, ainda possuíam a opção de reclusão doméstica, desde que isolados de qualquer contato com a família ${ }^{11}$.

Despidos de direitos pelo poder instituído, ainda precisavam lidar com as ideias punitivas e o julgamento social que acompanhavam a doença. Afinal, "qualquer enfermidade tida como um mistério e temida de modo bastante incisivo será considerada moralmente, se não literalmente, contagiosa”". A lepra, percebemos, nunca se restringiu a um mal físico ou biológico. Como reflete Carolina Oliveira, ela figura também como uma doença social. "Ao se falar em lepra, imediatamente vem à mente uma história de exclusão, preconceitos, um doente terrível, deformado, condenado à morte, isolado do convívio social desde os tempos bíblicos. A doença seria resultante do pecado, da promiscuidade, ou resultante de um carma. A 'purgação' ou o sofrimento em vida seria necessário para a remissão dos pecados. O leproso não era apenas um doente. Era a personificação, em muitos casos, do perigo, da monstruosidade, do medo". ${ }^{13}$

Desta forma, é preciso compreender que, além do medo de uma doença cujo tratamento era tão pouco conhecido, havia um medo igualmente latente da reclusão, da exclusão social e, é claro, da demonização que a envolvia. Percebemos, portanto, que o temor não dominava apenas os 'sãos', mas também os que, com suspeita de contágio ou mesmo nas fases iniciais da doença, se viam frente a uma iminente desumanização por parte da sociedade que os cercava.

Pierre Sastre, um ex-interno do Hospital Colônia da Mirueira, em Pernambuco, conta que após a década de 1950, graças a um novo tratamento médico, as portas do leprosário foram abertas, permitindo que os internos circulassem pelas redondezas. Ainda assim, os olhares de suspeita e julgamento nunca deixaram 
os enfermos. Certa vez, uma criança supostamente desapareceu na comunidade vizinha, e a resposta da comunidade se espalhou rapidamente: o culpado, definitivamente, era um dos internos. Um "Papa-Figo"15.

Corruptela popular de 'papa fígado', o nome indica uma criatura peculiar à mitologia popular do Nordeste brasileiro. Uma pessoa amaldiçoada que, sob os auspícios de uma doença incurável, precisa se alimentar do fígado de crianças para manter-se vivo. A crença se espalhou, e sempre que uma ambulância ia para o hospital, logo se ouviam as acusações: "Aí vai um menino! Aí vai fígado para os leprosos!"”5.

A partir daí, a situação degringolou, a ponto de os moradores da vizinhança montarem vigílias para alertar os demais contra a presença dos leprosos. Com o clima de medo constante, Sastre relata que se chegou ao cúmulo da perseguição. Certa vez, um desafortunado com o rosto todo inchado de picadas de marimbondo foi escorraçado aos gritos de morfético, leproso e, é claro, Papa-Figo. No entanto, o ex-interno não deixa de notar que, enquanto o ataque a pessoas com deformações passou a ser frequente, hansenianos que não manifestavam a doença visivelmente circulavam sem qualquer problema ${ }^{13}$. As mãos em garra, orelhas inchadas e caroços pelo corpo eram índices de monstruosidade que inspirava a desumanização.

A lepra encontrou seu lugar no imaginário em todas as classes sociais. Para os pobres, a certeza do abandono que já experimentavam por parte do poder. Para os ricos, todavia, o contágio ameaçava todos os privilégios outrora usufruídos. Não é de se estranhar, portanto, que atos grotescos tenham sido efetivamente implementados na busca de se livrar da doença. Escreve Cascudo: "Com a 'loucura pela saúde' o leproso é capaz de tudo. Sujeita-se aos remédios mais exóticos, às promessas incumpríveis, aos regimes inumanos. Tanto mais estranho, raro, novo, inacessível for o remédio, maior a fé e multiplicada a ânsia de sua utilização"16.

Não por acaso Papa-Figo é frequentemente representado como um homem abastado, capaz de com seu dinheiro cometer violações das mais terríveis para recuperar sua saúde. Um dos mais célebres registros do mito foi feito por Gilberto Freyre, em seu livro Assombrações do Recife Velho, publicado pela primeira vez em 1955. A história conta sobre o patriarca de uma família da alta sociedade recifense, que contraiu uma terrível moléstia sem nome. Desesperado para encontrar a cura que a ciência lhe negou, dizem que o homem procurou ajuda dos negros velhos. Um deles, por fim, lhe teria dito que só ficaria bom comendo o fígado de um menino. Contam ainda que o próprio negro, sob a proteção do branco opulento, se encarregou de perambular pelos arredores de Recife com um saco nas costas. "Ia recolhendo menino no saco e dizendo que era osso para refinar açúcar. Mas era menino. Carne de menino. Quanto mais corado e gordo o meninozinho, melhor"’ E sentencia: curou-se, mas de modo sinistro.

Assim se consolida o mito do Papa-Figo; não o sequestrador, mas o desejo monstruoso por trás dos sequestros. Um homem cuja vontade de viver era tão egoísta que passou por cima de qualquer moralidade em busca de sua cura. No processo, o tornar-se monstro que se iniciou pela aparência se consolida mesmo é nas ações imorais que buscam mascará-la.

Qual doença acomete o Papa-Figo? Gilberto Freyre fala na licantropia. O homem, com orelhas enormes, cara amarela e inchada, dentes a mostra, estava prestes a se transformar em lobisomem ${ }^{17}$. Cascudo, porém, crava sem muito espaço para dúvidas: orelhas inchadas, lábios retorcidos, rosto vermelho são sintomas da lepra. A própria relação com o elemento de cura dá o contexto: "Na terapêutica contra a lepra, o banho de sangue humano e a degustação do fígado, especialmente das crianças, são remédios tradicionais”" ${ }^{\text {”18. }}$

A tradição é realmente milenar, remetendo ao médico e filósofo grego Galeno de Pérgamo, que nasceu no ano 129 d.C. Médico oficial dos gladiadores e da família imperial romana, seus estudos de fisiologia serviram como herança para o desenvolvimento da medicina medieval e árabe. Para Galeno, a saúde era o equilíbrio entre quatro "humores", isto é, quatro líquidos: sangue, bile amarela (cólera), bile negra (fleuma, apatia) e pituíta (melancolia). E todos, menos esta última, seriam produzidos pelo fígado. "Galeno dizia que o fígado era como o princípio, foco e árbitro do corpo. O fígado formava o sangue. Dele partiam todas as veias. Recolhia tudo que penetrava no organismo pela via do intestino e (...) elaborava uma segunda e mais importante digestão, a que constituía a substância de toda aparelhagem fisiológica, dos tecidos e do sangue"18. 
Rescaldos desta medicina ancestral por certo sobreviveram ao longo de todo o período colonial, incorporados pelos portugueses que aqui desembarcaram. Mas esta é uma explicação insuficiente. Há um simbólico muito forte nessas duas imagens, do fígado e do sangue, que ajudaram a dar forma a essas narrativas que emergem do imaginário e que se consolidam em culturas as mais diversas em todo o mundo.

O que é o sangue? Ou melhor, o que este significa no âmbito do imaginário? Chevalier e Gheerbrant nos lembram que a imagem do sangue compartilha os mesmos valores simbólicos que aquelas do fogo, calor e da vida - sendo, por consequência, o veículo das paixões ${ }^{18}$. E esta é uma relação que permeia sociedades do mundo todo. Afinal, o fluxo sanguíneo e o calor corporal indicam um corpo vivo, diferente da imobilidade fria da morte. Não por acaso, em diversos mitos é o sangue (divino) que permite o nascimento de animais, plantas ou mesmo metais. É o símbolo do princípio geracional. Ou, como sintetiza a bíblia cristã, "Sangue é vida" 18 .

Essa relação, percebemos, era identificada tanto pela religião, quanto pela medicina e até mesmo pelas 'artes ocultas'. O mago Éliphas Lévi, citado por Cascudo, indica: "Sangue é o substrato da luz, vida materializada. É feito à imagem e semelhança do infinito"19. Está ligado então ao início e ao fim, vida e morte, elevação e purificação. Todavia, quando violado, ao que é pútrido e inferior, é sangue sujo, sangue ruim.

Para Galeno, o fígado era a fonte do sangue e sua influência na medicina ocidental certamente tornou essa relação mais flagrante. No entanto, há outras relações que se consolidam no imaginário. O mitólogo Junito de Souza Brandão pontua que o fígado era considerado em quase todas as culturas como centro da vida - e, se sangue é vida, a ligação com o fígado já se estabelece. Por derivação, os arroubos de paixão por vezes também eram relacionados ao órgão. Em algumas versões dos mitos gregos dizem que Eros, o amor, disparava flechas não contra o coração, mas contra o fígado das pessoas que deseja encantar¹.

"O fígado é comumente ligado aos movimentos da cólera, da ira, da animosidade e às intenções deliberadamente venenosas, o que explica o sabor amargo da bile"18. Mas se uma das faces da moeda das paixões movidas pelo fígado é a ira, a outra é a coragem. 'Ter fígado' é muitas vezes utilizado para designar aquele que tem ímpeto, bravura, força. A ponto de, na China da Antiguidade, já foi costume comer o fígado dos inimigos para personificar tais qualidades ${ }^{18}$.

Não se pode deixar de mencionar uma outra particularidade do fígado que atravessa biologia e mitologia: a sua capacidade regenerativa. É ele o único órgão capaz de se regenerar quando lesado, algo que se mostra explicitamente no mito de Prometeu - o titã condenado por Zeus a ter seu fígado diariamente dilacerado por uma ave, apenas para que ele se cure e torne a ser atacado no dia seguinte. No caso específico de Prometeu, o simbólico da regeneração fica em segundo plano. O motivo, explica o filósofo Bernard Stiegler, é que em diversas sociedades ocidentais o fígado é utilizado para a prática da "hermenêutica adivinhatória", de onde se interpretam as mensagens divinas durante o sacrifício ${ }^{20}$. Assim, percebemos, o papel da águia ao conter a potência divinatória de Prometeu, cujo nome significa 'Aquele que vê antes', submetendo-o ao controle do mito do poder, Zeus.

Como isso se articula com nosso objeto de investigação? A lepra, sabemos, é um problema da pele. Mais especificamente, uma doença infecciosa causada pelo bacilo de Hansen, que causa danos nos nervos e na pele. Na tradição popular, no entanto, a lepra é uma doença do sangue, um sintoma de que 'o sangue está apodrecendo'. Assim, se o fígado é entendido como o produtor do sangue, aí é que está o remédio. Diante desta lógica, um fígado doente trata-se com um fígado sadio. Afinal, como já introjetado pela medicina ancestral, o semelhante cura o semelhante ${ }^{19}$.

No início deste artigo, lembramos como o cristianismo ajudou a consolidar a ideia da doença como culpa individualizada. Pois dentro do imaginário cristão, encontramos nos contos populares que tanto se espalharam durante o medievo diversas citações à lepra como um castigo divino. Na Legenda Dourada, conhecido tomo de hagiografias - as biografias dos santos -, destacamos a história da maldição imposta ao imperador Constantino. Após perseguir o monge São Silvestre, o governante foi acometido por uma 
lepra incurável. A terapêutica sugerida pelos clérigos pagãos da narrativa dialoga muito com elementos que vamos encontrar ao longo dos séculos: "A conselho dos sacerdotes dos ídolos, trouxeram-lhe 3 mil crianças para serem degoladas e para que, em seguida, ele se banhasse em seu sangue fresco e quente"21.

A pulsão arquetípica é fundamental para dar forma às imagens sobre nossa relação com a doença. No entanto, há um outro elemento a ser considerado: a pulsão histórica, que será distorcida pela fantasia popular, convidando à fabulação. Do seu entrecruzamento, teremos a consolidação dos mitos.

\section{Reminiscências}

Identificamos sangue e fígado como as principais imagens simbólicas sobre as quais constelam as demais que vão dar forma a este imaginário sobre a lepra. Para nos aprofundarmos nesta identificação de imagens, faz-se necessário centrar em uma narrativa mais específica para a partir dela encontrarmos mais elementos para investigar.

Encontramos a personagem ideal para esta abordagem na figura de Amélia Duarte Machado, conhecida no Rio Grande do Norte como a 'viúva Papa-Figo'. Dona Amélia se casou em 1904 com Manuel Machado, um distinto comerciante português, passando a integrar a alta sociedade natalense. Ariana Medeiros, autora de uma tese sobre o caso da viúva, resgata que na época era comum que a mulher assumisse um papel importante dentro de uma família burguesa: deveria organizar jantares e recepções, abrir sua casa para a apreciação pública de amigos e parentes, e sempre se submeter a opinião dos outros. "Essa mulher de elite que passou a marcar presença em teatros, bailes, café e reuniões sociais, parecia ser mais 'livre', porém era submetida a uma vigilância maior, que não se restringia ao marido, mas aos olhares atentos da sociedade"22.

Na década de 1930, Manuel Machado faleceu. Amélia, então, assumiu os negócios do marido. Com a viuvez, de mulher culta e religiosa, dama da sociedade, Amélia passou a ser rica comerciante, administrando ativamente os negócios e se fechando à vida social que a burguesia lhe exigia. Dentro da própria aristocracia começaram os boatos. A vida pessoal rapidamente entrou em pauta. A mulher não tinha filhos. E mais: durante todo seu casamento, ela engravidou várias vezes, mas sem nunca ter conseguido conceber. Certamente algum castigo divino, diziam as más línguas ${ }^{22}$. E se não aparecia em público, deveria ser por algum motivo. Não tardou para que se espalhassem histórias de que havia contraído lepra.

A difamação surtiu efeito. Ainda em vida, a mulher passou a ser temida como um monstro, tal qual todos os hansenianos da época. O folclorista Gutemberg Costa, em livro sobre personagens famosos de Natal, recolhe uma versão: "A Viúva Machado é rica e tem um empregado andando de carro em Natal, só para pegar criancinhas. São elas levadas à noite a sua casa e, depois da retirada do fígado, são devolvidas com a barriga cortada recheada de dinheiro"²1. Ele próprio se recorda das histórias que ouvia de sua família, que diziam que a mulher possuía um poço bem fundo em seu quintal cheio de cobras venenosas onde os corpos das crianças, já esvisceradas, eram lançados ${ }^{23}$.

Ariane Medeiros reúne a opinião de diversos biógrafos e especialistas e conclui: os próprios ricos, incapazes de lidar com uma mulher que assumisse um lugar de poder, espalharam a boataria ${ }^{22}$. Histórias que ficaram tão forte que, mesmo após sua morte, em 1981, muita gente ainda acredita nas narrativas contadas sobre ela. E sua morada entrou no imaginário popular como a 'casa da viúva Papa-Figo'.

Quando se fala na residência de Amélia Machado em Natal, dois espaços são frequentemente referenciados. O primeiro é o palacete construído próximo à Igreja do Rosário, no bairro Cidade Alta - uma construção suntuosa que ainda hoje é habitado pelos membros de sua família. Já o segundo, e este sim alimenta as narrativas populares, é um casarão comercial abandonado no bairro Guarapes. O local teria pertencido à família Machado e atualmente se encontra em ruínas, tomado pela vegetação e atraindo os olhares dos curiosos que hoje, num contexto de sociedade midiatizada, recirculam as histórias sobre a casa da 'viúva Papa-Figo' à revelia da factualidade dos acontecimentos. 
Este fenômeno é reflexo de um processo comunicacional a ser ainda melhor investigado. Ocorre que um gênero que vem ganhando certa notoriedade no YouTube é o de vídeos de exploração urbana, nos quais os produtores de conteúdo redescobrem as cidades a partir de uma incursão, filmada, a ruínas, casas ou prédios abandonados.

Esse movimento, como esclarece Souza: “Tem como campo de ação a cidade proibida, os locais onde a vitalidade das trocas sociais se esvaiu e apenas a concretude dilapidada oferece-se como um cenário, como um ambiente peculiar para a experiência da busca do espanto e do inusitado, permeado de riscos e perigos inerentes à transgressão dessa atividade"24.

Ao construir novas narrativas que ressignificam a cidade, por vezes, o produtor recorre à ficcionalização do relato de modo a gerar maior engajamento. Isso se torna ainda mais evidente quando as ruínas visitadas já estão imbuídas, no imaginário popular, de uma aura de mistério, fornecendo o combustível ideal para o envolvimento nas redes. Assim, surgem grandes canais voltados para a exploração de 'casas assombradas' com foco no sobrenatural, nos quais a visita filmada é acompanhada de trilha sonora, edição dramática e narração que sensacionaliza as factualidades que envolvem o espaço retratado em vídeo.

Existe toda uma estética construída para esses vídeos a partir da relação com o YouTube enquanto meio de circulação do conteúdo. Tendo em vista os melhores formatos para otimizar a rentabilidade do canal, os vídeos de exploração são normalmente longos - de modo a comportar um maior número de anúncios - e carregam na tensão com o objetivo de reter o espectador até o final, mantendo assim números valiosos para o marketing. As visitas também são normalmente serializadas, sendo que a continuação que promete maior desafio (ir à noite, ir sozinho etc.) só é liberada se o público responder positivamente, fazendo com que o vídeo atinja um número determinado de curtidas compactuado no próprio produto audiovisual.

Interessante é perceber que a mesma estética que orienta tais produções no contexto das metrópoles acaba sendo apropriada por produtores de conteúdo periféricos e que, mesmo com canais pequenos demais para serem monetizados pelo YouTube ${ }^{i i i}$, mimetizam o formato dos canais de referência. Sua peculiaridade é oferecer conteúdo regionalizado, fazendo com que narrativas outrora restritas às suas comunidades locais alcancem as redes e expandam o alcance da oralidade.

Encontramos três canais com vídeos recentes que mostram incursões ao casarão de Guarapes e que recorrem ao lendário para a promoção do conteúdo: a) IncrívelMente Curioso, com 3.250 inscritos; b) Embusca de lendas, com 25 inscritos e c) Detectors in action nordeste Brasil, com 17 inscritos ${ }^{\text {iv }}$. O primeiro, e mais bem estruturado, é o que mais segue o formato dos canais de referência. Os outros dois, por menores que sejam, também seguem algum padrão: se comunicam diretamente com o público, narram o percurso feito, pedem para curtir, compartilhar e seguir o canal.

Os três são captados pelo celular, com bastante movimentação da câmera, dando o estilo de filmagem amadora já consagrado no audiovisual de terror com Bruxa de Blair (1999). Há, todavia, uma nítida distinção técnica do IncrívelMente Curioso, que utiliza recursos de edição como a mudança de temperatura de cor da imagem para dar impressão de anoitecer e aumentar o clima de tensão desejado. Embora todos os canais sejam voltados para a exploração urbana, o último não tem como foco o sobrenatural propriamente dito, mas sim a busca por tesouros enterrados por meio do uso de um detector de metais.

O IncrívelMente Curioso fez duas visitas ao casarão. Na primeira, após 'procurar' as covas onde a viúva teria enterrado crianças, promete retornar durante a noite, caso a meta de 500 likes fosse batida ${ }^{25}$. Nem 10\% do objetivo foi atingido, mas ainda assim após seis meses um novo vídeo é publicado no local, retomando a busca de marcos de interesse no terreno que circunda o casarão ${ }^{26}$. Em ambos os vídeos, os jovens produtores de conteúdo percorrem o perímetro com facas, dando golpes a esmo contra a vegetação

iii Desde 2018, apenas canais com mais de mil inscritos e com, no mínimo, quatro mil horas de conteúdo assistido nos últimos 12 meses podem ser aceitos no programa de parcerias com o YouTube, que permite a monetização.

iv Números relativos ao dia 15 de abril de 2020. 
e reclamam da mata fechada - mesmo que a imagem diga o contrário. No retorno durante a noite, camisas camufladas e uma lanterna de celular servindo de spotlight dão o tom da narrativa ${ }^{26}$.

Acompanhando a estética do sensacionalismo estão os trechos da lenda incorporados no audiovisual. O apresentador explica que aquele era o lugar onde a viúva 'matava geral' e, após comer o fígado das crianças, jogava seus corpos em um poço. Como não havia nenhuma evidência material da existência de um poço no casarão, o vídeo sugere que o lugar possa ter sido tampado com pedras. Ainda assim, as almas das pessoas mortas ainda estariam por ali, presas dentro da vala escondida ${ }^{25}$.

Os vídeos tanto o da visita durante o dia quanto o da que ocorreu durante a noite terminam de maneira semelhante: uma correria provocada por um pretenso avistamento de algo misterioso: um 'bicho', 'alguém'. A imagem nada mostra, mas a narrativa estimula o olhar, insistindo que há algo ali para onde a câmera aponta. O público, por mais enxuto que seja, se envolve e pergunta nos comentários o que aconteceu, o que foi visto, e pede detalhes. $\mathrm{O}$ objetivo acaba sendo cumprido.

O Detectors in action, por sua vez, encontrou uma vala para dar a ver no vídeo. O produtor de conteúdo também menciona o caso das crianças assassinadas, e sugere que o local "provavelmente" era usado para a desova de $\operatorname{corpos}^{27}$. Como o foco do canal não é o sobrenatural, o apresentador ressalta que o intuito não era encontrar ossadas, mas ver que materiais poderiam estar ocultos no fundo do poço. Após percorrer com o detector de metais na superfície, encontrando não mais que pregos antigos, decide descer o celular por uma corda pelo poço. O resultado é muito pouco visível, e a tentativa de chegar ao fundo fracassa.

Por fim, no canal Embusca de lendas, encontramos pela primeira vez a menção de uma doença que teria acometido a viúva Machado - ainda que no vídeo não se fale qual enfermidade seria essa. $\mathrm{O}$ apresentador relata que, no casarão, era comum receber visita de pais dispostos a vender suas crianças para que fossem utilizados na profilaxia da mulher. Conforme o vídeo, a lenda sobre o local dizia que a proprietária da casa tinha orelhas muito grandes, e que precisava comer o fígado das crianças para que elas diminuíssem ${ }^{28}$.

Conforme caminha em direção ao casarão, o apresentador menciona que estão "se aproximando da lenda”28. É uma observação interessante, uma vez que a espacialidade na qual a narrativa popular indica que ocorreu o episódio fantástico se torna uma coisa só no imaginário da comunidade. Sua existência física atua como uma comprovação do ocorrido, capaz de ser não apenas explorado como representado em vídeo pela câmera.

\section{Conclusões}

Observemos, portanto, as redundâncias de imagens nas narrativas sobre a viúva Machado - presentes nos vídeos e nos relatos sobre ela. Uma das que mais salta aos olhos é a imagem do poço, local de esconderijo de cadáveres, prisão das almas, índice físico daquilo que se oculta. Chevalier e Gheerbrant relacionam a simbólica do poço a alguns elementos-chave, sendo um deles a conexão entre este mundo (o da superfície, o que se mostra) e o outro, o submundo. Outra forma de adentrar neste mundo do oculto é a visita ao espaço da lenda durante a noite, quando as fronteiras entre sonho e realidade são mais borradas. É lá, neste lugar próximo-distante, onde a luz do sol não chega, que se esconde a verdade. Aos pés do poço, símbolo do segredo e da dissimulação, experimentamos a sensação do abismo, da descida, da interiorização. Se há água ao fundo, guarda nas suas entranhas o reflexo de nós mesmos ${ }^{18}$.

Não por acaso, há recorrências nos atos vinculados ao desvelamento e à revelação. São as facas que rompem a 'mata fechada' para abrir caminhos, as lanternas que lançam luz sobre a escuridão, a câmera do celular descendo na corda em direção ao fundo, o detector de metais que busca identificar o que os olhos são incapazes de perceber. $\mathrm{O}$ enterramento, vale lembrar, está frequentemente ligado não apenas a relatos de morte, mas de tesouros, em um imaginário que se inter-relaciona ${ }^{29}$. São os segredos que a terra esconde: o 
ouro, os metais preciosos, mas também as ossadas ocultas. A própria verdade escamoteada, quando trazida à luz, faz as vezes de tesouro descoberto.

Se o ouro carrega o simbólico da pureza, do fogo, de reflexo da luz celeste ${ }^{18}$, o dinheiro é sua imagem desbastada, maculada. E é esse dinheiro, sujo, que é colocado dentro dos corpos das crianças mortas, já sem o fígado, numa mercantilização da vida recorrente aos poderosos. Derivação deste ato é o desespero que leva os próprios pais, na narrativa popular, a venderem as crianças para o monstro. $\mathrm{O}$ temor é que nossa vida tenha menos valor que um punhado de notas.

Uma outra imagem recorrente é a do Outro misterioso. Nos vídeos, é aquele que se faz aparecer sem se mostrar; seja com barulhos, movimentos de câmera ou a performance dos apresentadores. Nas narrativas, é essa figura alheia a nós, a quem não reconhecemos como semelhante e que nos gera temor. Nas histórias sobre o Papa-Figo que mencionamos anteriormente, normalmente esse estranho nunca é o dono do poder, mesmo sendo ele o agente principal da história. É sempre o negro, o cigano, o velho do saco sequestrador, o hanseniano com deformações físicas. Assim, miticamente, os verdadeiros monstros permaneciam a distância, indiferentes, inescrupulosos, agindo nas sombras e intocáveis graças aos escudos do poder.

Amélia Machado, por outro lado, não tem o mesmo status intocável, ainda que tenha sido detentora de poder (econômico), por uma questão muito particular: o gênero. Mulher solteira, sem filhos e administradora de riquezas, ela gerava no seu grupo social desconforto tamanho que houve espaço para a fabulação. Assim, a deformação física frequentemente mencionada (orelhas inchadas) seria reflexo de uma corrupção interna - no sangue, no espírito. O mesmo se pode dizer dos julgamentos sociais aos seus abortos espontâneos, representação de um castigo divino por alguma falta misteriosa.

Apenas renovando esse sangue corrompido, incapaz de ser transmitido adiante, é que seria possível a sobrevivência do Papa-Figo. Para isso, consome-se o fígado puro de uma criança: símbolo de renovação, tentativa de recuperar a vitalidade, a coragem, a paixão. O oposto disso é a decadência do corpo e da alma, apatia, morte em vida. A reclusão do doente e sua posterior exclusão social são índices deste apagamento a ser temido nas narrativas.

Tendo analisado as imagens que constelam em torno do imaginário da lepra a partir do mito do PapaFigo, percebemos que o nome da doença e suas características podem até se perder, mas os medos e agonias arquetípicas sobrevivem. Devido ao avanço nos tratamentos, a lepra é hoje algo tão distante da realidade da população que o próprio modo de se referir à doença - hanseníase - já se afasta da praga de tempos bíblicos que acometia os lázaros. Sem o temor imediato quanto ao contágio, o rescaldo deste imaginário da doença persiste nos elementos de desumanização. Por um lado, nos sintomas físicos que remetem à animalidade (orelhas grandes, lábios retorcidos etc.); por outro, na própria reação daquele que sofre do mal que, na narrativa popular, renunciaria à moral mais básica em nome da própria cura. Com nossa alteridade recusada, resta a interiorização, o olhar para as profundezas do abismo e ver nele nossas próprias deformidades de caráter.

No caso da viúva Machado, o desbastamento é ainda mais palpável. Seus feitos enquanto figura histórica se perdem, restando no imaginário apenas fragmentos da própria lenda urbana. Sua suposta doença, os motivos para os alegados sequestros de crianças, tudo persiste como as ruínas do casarão do Guarapes. O que sobra é o medo residual, que permanece alimentado pelo espetáculo e pela performática das redes sociais.

\section{Referências}

1. Brandão JS. Mitologia grega. Petrópolis, Brasil: Vozes; 2011.

2. Sontag S. Doença como metáfora - Aids e suas metáforas. São Paulo: Cia das Letras; 2007.

3. Barthes R. Mitologias. Rio de Janeiro: Difel; 2010.

4. Durand G. Mitos y sociedades: introducción a la mitodologia. Buenos Aires: Biblos; 2003. 
5. $\quad$ Bachelard G. O ar e os sonhos: ensaio sobre a imaginação do movimento. São Paulo: Martins Fontes; 1990.

6. $\quad$ Néia VHS. O folclore e a escrita da História: a cultura popular como fonte. Resgate: Revista Interdisciplinar de Cultura. 2017;25(1):203-26.

7. Maffesoli M. O imaginário é uma realidade. Revista Famecos. 2001;(15):74-82.

8. Kitta A. The kiss of death: contagion, contamination and folklore. Utah: University Press; 2019.

9. Bíblia. Tradução de João Ferreira Almeida. Rio de Janeiro: King Cross Publicações; 2008. 1110 p. Velho Testamento e Novo Testamento. Luc 16.19-31.

10. Anchieta J. Cartas: correspondência ativa e passiva. Obras completas, v. 6. São Paulo: Edições Loyola; 1984.

11. Maurano F. História da lepra no Brasil e a distribuição geográfica. In: Serviço Nacional de Lepra. Tratado de Leprologia. Rio de Janeiro: Ministério da Saúde; 1960. p. 17-168.

12. Ramos A. Castigos dos escravos. Revista do Arquivo Municipal. 2019;47(1):79-104.

13. Oliveira CPM. Memórias de Lázaro: relatos sobre lepra e exclusão no século XX. Cadernos de História UFPE. 2010;7(7):205-35.

14. Garcia MF. Leprosários: internação à força e 40 mil bebês tirados dos pais. Observatório do terceiro setor [Internet]. 2018 fev. 2 [citado em 2019 ago. 11]. Disponível em: https://observatorio3setor.org.br/ carrossel/leprosarios-brasil-isolamento-forcado-e-40-mil-bebes-arrancados-dos-pais-forca/.

15. Sastre P. Os ilhados. Recife: Universidade Federal de Pernambuco; 1971.

16. Cascudo LC. Geografia dos mitos brasileiros. São Paulo: Global; 2012.

17. Freyre G. Assombrações do Recife Velho. Rio de Janeiro: José Olympio; 1974.

18. Chevalier J, Gheerbrant A. Dictionnaire des symboles. 11 ed. Paris: Robert Laffoni et Jupiter; 1990.

19. Cascudo LC. Dicionário do folclore brasileiro. Rio de Janeiro: Global; 2012.

20. Stiegler B. La técnica y el tiempo: el pecado de Epimeteo. Hondarribia: Editorial Hiru; 2002.

21. De Varazze J. Legenda Áurea. São Paulo: Cia das Letras; 2003.

22. Medeiros ALSR. Amélia Duarte Machado, a Viúva Machado: a esposa, a viúva e a lenda da Cidade do Natal (1900-1930). [dissertação]. Programa de Pós-Graduação em História. Universidade Federal do Rio Grande do Norte. Natal; 2014.

23. Costa GM. Natal: personagens e populares. Natal: RN Econômico; 1999.

24. Souza RF. Lugares abandonados: decadência urbana e desolação na cidade. Triades [Internet]. 2019 Jun [citado 11 ago. 2019];1(2):135-50. Disponível em: https://triades.emnuvens.com.br/triades/article/ view/204.

25. IncrívelMente Curioso. Visitamos a casa assombrada da viúva machado e fomos surpreendidos [Internet]. 2018 dez. 24 [citado em 06 abr. 2020]. Disponível em: https://youtu.be/wBKOYnu14M4

26. IncrívelMente Curioso. Fui na casa da viúva machado de noite aconteceu algo assustador [Internet]. 2019 jul 18 [citado em 06 abr. 2020]. Disponível em: https://youtu.be/k4eSjb7h6zY

27. Detector in action nordeste Brasil. Filmei o fundo do poço tirem suas conclusões [Internet]. 2018 out. 29 [citado em 06 abr. 2020]. Disponível em https://youtu.be/PyS erwYKU4

28. Embusca de lendas. Fomos na lenda da viúva machado de dia [Internet]. 2018 dez. 11 [citado em 06 abr. 2020]. Disponível: https://youtu.be/0IOTx1sjNTI.

29. Costa A. A lenda nas páginas do jornal - a presença do imaginário no jornalismo a partir da cobertura dos tesouros enterrados no Paraguai. [dissertação]. Programa de Pós-Graduação em Jornalismo. Universidade Federal de Santa Catarina; 2013. 